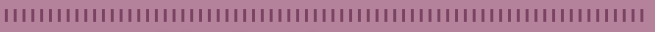
診療ガイドライン

at a glance

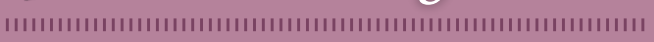

\section{喘息予防・管理 ガイドライン2015}

\section{Key words}

喘息コントロール，気道可逆性，気道過敏性， 気道炎症, 変動性気道狭窄

〔日内会誌 $106 ： 1165 １ 170 ， 2017 〕$

\section{一ノ瀬 正和}

東北大学大学院内科病態学講座呼吸器内科学分野

\section{Masakazu Ichinose}

Department of Respiratory Medicine, Tohoku University Graduate School of Medicine, Japan.

\section{はじめに}

喘息は多様な病因や増悪因子，誘発因子によ り多彩な描像を示し,「症候群」ともとらえられ る。疾患の本態は気道壁の炎症（通常好酸球を 主体とした細胞浸潤）であり，さらに遺伝的， あるいは炎症から2次的に獲得される気道過敏 性克進（少しの刺激で気道が過度に収縮する反 応）が喘息病態を修飾する。

気管支喘息罹患率は一般的にはアンケートに よって調査されるが，喘息罹患率は世界的にみ てこの30年間で増加傾向にあり, 日本では成人 の喘息罹患率は2006年調査で約 $8 \%$ と推定され る. また, 日本の喘息死の動向を厚生労働省人 口動態統計でみると, 人口 10 万対の喘息死亡総 数は 1975 年頃からほぼ横這い状態で，1995年 に一過性に増加したが，1997年からさらに減少 し，1980年 6,370 人であったのが 2013 年には $1,728$ 人まで減少した (図 1$)^{11}$. こういった喘息 死の減少に「喘息予防・管理ガイドライン」は 大きく貢献していると考えられる.

「喘息予防・管理ガイドライン」は2004年に 日本アレルギー学会の常設委員会として「アレ ルギー疾患ガイドライン委員会/喘息ガイドラ イン専門部会」が発足し，2006年に「喘息予 防・管理ガイドライン2006」が発刊されて以 来, 3 年ごとに改訂され, 今回の「喘息予防・ 管理ガイドライン 2015」（JGL2015）に至る.

\section{1. 喘息の定義}

JGL 2015 では，喘息は，「気道の慢性炎症を 本態とし, 臨床症状として変動性を持った気道 狭窄 (喘鳴, 呼吸困難) や咳で特徴付けられる 疾患」であると定義された ${ }^{1}$. さらに, 気道炎 症に関して,「好酸球, 好中球, リンパ球, マス 卜細胞などの炎症細胞, 加えて, 気道上皮細胞, 線維芽細胞, 気道平滑筋細胞などの気道構成細 胞，および種々の液性因子が関与する。自然に, 


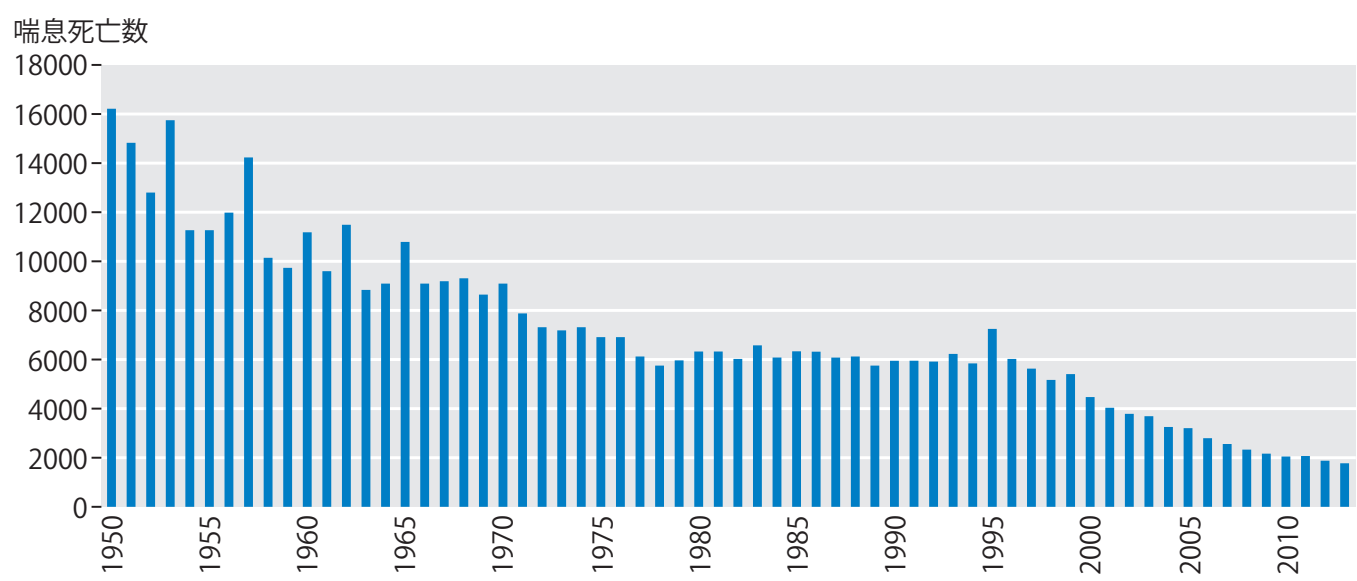

図 1 喘息死総数の年次推移（文献1より引用）

\section{表 1 喘息診断の目安 (文献1より引用)}

1. 発作性の呼吸困難，喘鳴，胸苦しさ，咳（夜間， 早朝に出現しやすい) の反復

2. 可逆性の気流制限

3. 気道過敏性の元進

4. アトピー素因の存在

5. 気道炎症の存在

6. 他疾患の除外

・上記の 1，2，3，6が重要である.

・4，5の存在は症状とともに喘息の診断を支持する.

・5 は通常, 好酸球性である.

あるいは治療により可逆性を示す気道狭窄は, 気道炎症や気道過敏性六進による。持続する気 道炎症は, 気道傷害とそれに引き続く気道構造 の変化（リモデリング）を惹起して非可逆性の 気流制限をもたらす」と記載されている.

\section{2. 喘息の診断}

喘息の定義で述べたように「変動性を持った 気道狭窄」が顕著な症例では, 喘息の診断は容 易だが, 変動性が軽微な場合や症状が咳のみの 場合は喘息の診断に難渋する場合がある. JGL2015 では表1に示すような喘息診断の目安 を 6 項目挙げ, それぞれの項目の重み付けも 行っている.
1）発作性の呼吸困難，喘鳴，胸苦しさ，咳

（夜間，早朝に出現しやすい）の反復

喘息では夜間や早朝に喘鳴や咳などの症状が 出現しやすい。これは夜間や早朝には, 寝具か らの抗原吸入量が増えることや, 交感・副交感 神経のバランスが副交感優位に傾くこと, 内因 性のステロイド分泌量の低下などが関与している.

\section{2）可逆性を持った気流制限}

気流制限は喘鳴や息苦しさといった症状に現 れる大きな変化から, 呼吸機能検査でわかる微 小な変化まで幅広く起こる.

\section{（1）気道可逆性試験}

短時間作用性 $\beta_{2}$ 刺激薬 (short-acting $\beta_{2}$ agonist：SABA）吸大後 15 30 分 でFEV (forced $^{2}$ expiratory volume in one second）が $12 \%$ 以上増 加, かつ絶対量で $200 \mathrm{ml}$ 以上増加する場合に有 意と判定するが, 喘息に特異的ではなく, COPD (chronic obstructive pulmonary disease) でも有 意な変化を示す場合があることに注意を要する.

\section{（2）治療や自然経過による気流制限の変動}

喘息では治療や自然経過によって $\mathrm{FEV}_{1}$ が有 意に変化する場合がある. PEF (peak expiratory flow）值の変動の場合は $20 \%$ を超えた変化は可 逆性の気流制限を示唆する. 


\section{表 2 喘息と鑑別すべき他疾患（文献1より引用）}

1. 上気道疾患: 喉頭炎, 喉頭蓋炎, vocal cord dysfunction (VCD，声帯機能不全)

2. 中枢気道疾患: 気管内腫瘍, 気道異物, 気管軟化 症，気管支結核

3. 気管支〜肺胞領域の疾患 : COPD

4. 循環器疾患 : うつ血性心不全, 肺血栓塞栓症

5. 薬剤: アンジオテンシン変換酵素阻害薬などの薬物 による咳

6. その他：自然気胸，過換気症候群，心因性咳嗽

\section{3）気道過敏性の亢進}

気道過敏性測定は, 通常, 気道平滑筋・血管 を直接的に刺激して気道狭窄を起こすアセチル コリンやメサコリン吸入による直接刺激法で行 う。一方，運動による過換気（結果起こる気道 粘膜面の高浸透圧や冷却化）によるマスト細胞 刺激後に起こるメディエーター放出, 或いは知 覚神経からのアセチルコリン放出を介して二次 的に気道狭窄を起こす間接刺激法もある.

\section{4）アトピー素因の存在}

特定の環境アレルゲンに対する即時型皮膚反 応, 特異的IgE抗体または吸入誘発試験が陽性で あればアトピー型喘息である。

\section{5）気道炎症の存在}

通常は好酸球性であり, 喀痰中の好酸球の増 加は診断的価值が高い. 呼気一酸化窒素濃度は 気道の好酸球浸潤の程度と相関性を示すため, 診断補助として有用である.

\section{6）他疾患の除外}

表 2 に示す疾患が鑑別診断すべき疾患として 挙げられる。

\section{3. 㟨息の管理目標}

喘息の管理では, 疾患の本態である気道炎症 を制御し気道過敏性を抑制することに加え, 十 分な気管支拡張により症状を軽減することが重 要である. 気道炎症制御には抗原回避に代表さ れる原因の除去と吸入ステロイド（inhaled corticosteroids：ICS）を中心とした薬物療法が推奨 される．気管支拡張が十分であるかどうかは， 症状聴取に加え呼吸機能の測定が有用である. JGL2015では，喘息の管理目標に，1）健常人 と変わらない日常生活を送ることができる，2） 非可逆的な気道リモデリングへの進展を防ぎ, 正常に近い呼吸機能を保つ，3）夜間・早朝を 含めた喘息発作の予防，4）喘息死の回避，5） 治療薬による副作用発現の回避の5 項目を挙げ ている.

\section{4. 喘息治療}

喘息治療薬は, 継続的に使用しコントロールを 目指す長期管理薬と喘息発作治療のために短期的 に使用する発作治療薬の2種類に分けられる ${ }^{1,2)}$.

\section{1）長期管理薬}

長期管理薬には，抗炎症作用を持つ薬剤と長 時間作用性の気管支拡張作用を持つ薬剤, 両者 の作用を持つ薬剤があるが，中でも，気管支喘 息の慢性気道炎症に関与する多彩な細胞群に広 く作用点を持つICSが第一選択薬である. ICSで コントロールが不十分な場合, 長時間作用性 $\beta_{2}$ 刺激薬（long-acting $\beta_{2}$ agonist：LABA）, 長時間 作用性抗コリン薬 (long-acting muscarinic antagonist : LAMA）のチオトロピウム・ソフト ミストインヘラー, テオフィリン，ロイコトリ エン受容体拮抗薬 (leukotriene receptor antagonist：LTRA）が長期管理薬の追加薬として用い られる. 以上の薬剤でコントロール不十分な場 合はIgE抗体，経口ステロイドを用いる. 
表 3 喘息コントロール状態の評価（文献1より引用）

\begin{tabular}{|c|c|c|c|}
\hline & $\begin{array}{l}\text { コントロール良好 } \\
\text { (すべての項目が該当) }\end{array}$ & $\begin{array}{c}\text { コントロール不十分 } \\
\text { (いずれかの項目が該当) }\end{array}$ & コントロール不良 \\
\hline 喘息症状（日中および夜間） & なし & 週 1 回以上 & \multirow{5}{*}{$\begin{array}{l}\text { コントロール不十 } \\
\text { 分の項目が } 3 つ \text { } \\
\text { 上当てはまる }\end{array}$} \\
\hline 発作治療薬の使用 & なし & 週 1 回以上 & \\
\hline 運動を含む活動制限 & なし & あり & \\
\hline $\begin{array}{l}\text { 呼吸機能 } \\
(\mathrm{FEV} \text { 1およびPEF) }\end{array}$ & $\begin{array}{c}\text { 予測值あるいは } \\
\text { 自己最良値の } 80 \% \text { 以上 }\end{array}$ & $\begin{array}{c}\text { 予測値あるいは } \\
\text { 自己最良値の } 80 \% \text { 未満 }\end{array}$ & \\
\hline PEFの日（週）内変動 & 20\%未満*1 & $20 \%$ 以上 & \\
\hline $\begin{array}{l}\text { 増悪 } \\
\text { (予定外受診, 救急受診, 入院) }\end{array}$ & なし & 年に 1 回以上 & 月に 1 回以上*2 \\
\hline
\end{tabular}

\section{2）発作治療薬}

発作治療薬は, 長期管理中に発作が生じたと きに用いる薬剤であり，作用の発現までに時間 が短いSABAの吸入薬, 経ロステロイド薬, テオ フィリン薬, 吸入抗コリン薬がある.

\section{5. 段階的薬剂投与プラン}

JGL2015は, 国際的な喘息ガイドラインの代 表である「Global Initiative for Asthma」(GINA) ${ }^{3)}$ と同様に, 重症度ではなく治療内容の強弱に 沿ったステップとしている.

喘息治療においては, 表3に示したような基 準で判断してコントロール良好を目指す。初期 治療がいかに有効であるかが患者と医師の信頼 関係構築上大きいので, まず, 喘息症状の改善 と安定を図る. 現在の喘息治療は薬剤によるコ ントロールが中心であるが, 薬剤のみに頼らず 感作アレルゲン (ダニ, 真菌, ゴキブリ, 動物, 花粉など）の回避や受動・能動喫煙, 過労など をも含めた増悪因子の回避, 除去に努めること も重要である。さらに，アレルギー性鼻炎や COPDなどの合併がある場合, 喘息管理が困難 になる場合が多いので注意を要する.

喘息治療はその強度から 4 つの治療ステップ
に分けられる (表4)。薬剤治療の目標は最小限 の薬剤で最大の効果を得ることである. 受診時 の症状と治療状況を総合的に評価して, どの治 療ステップが適切であるかを決定する.以下に JGL2015に記載されている各治療ステップに関 して概略を記す ${ }^{11}$ 。

\section{1）治療ステップ 1}

軽い喘息症状がごく稀（月 1 回未満を目安） にしか生じない患者に限り，喘息症状があると きにSABAを頓用し, 原則として長期管理薬は必 要としない. しかし, 喘息患者は症状の過少申 告が多いので注意する。ただし, 症状が月 1 回 以上の患者に対する長期管理薬としては, ICS （低用量）を用いる。

\section{2）治療ステップ 2}

ICS（低用量）とLABAの併用が推奨される. ICS とLABAは, 配合薬を用いた方が個々に吸入 するよりも有効性が高く, ICS とLABAの配合剂 による初期治療はICS単剤に比べて症状や呼吸 機能をより速やかに改善する. LTRAはアレル ギー性鼻炎合併例の長期管理に有用である.

\section{3）治療ステップ 3}

ICS（中～高用量）とLABAの併用が推奨され 
表4 喘息治療ステップ (文献1より引用)

LAMAは治療ステップ3-4で使用が推奨されている.

\begin{tabular}{|c|c|c|c|c|c|}
\hline & 治療ステップ 1 & 治療ステップ 2 & 治療ステップ 3 & 治療ステップ 4 \\
\hline \multirow{9}{*}{$\begin{array}{c}\text { 長期 } \\
\text { 管理 } \\
\text { 薬 }\end{array}$} & \multirow{8}{*}{$\begin{array}{l}\text { 基本 } \\
\text { 治療 }\end{array}$} & $\begin{array}{c}\text { 吸入ステロイド薬 } \\
\text { (低用量) }\end{array}$ & $\begin{array}{c}\text { 吸入ステロイド薬 } \\
\text { (低〜中用量) }\end{array}$ & $\begin{array}{c}\text { 吸入ステロイド薬 } \\
\text { (中～高用量) }\end{array}$ & $\begin{array}{c}\text { 吸入ステロイド薬 } \\
\text { (高用量) }\end{array}$ \\
\hline & & $\begin{array}{l}\text { 上記が使用できない場合は } \\
\text { 以下のいずれかを用いる }\end{array}$ & $\begin{array}{l}\text { 上記で不十分な場合に以 } \\
\text { 下のいずれか 1剂を併用 }\end{array}$ & $\begin{array}{l}\text { 上記に下記のいずれか } 1 \\
\text { 剂，あるいは複数を併用 }\end{array}$ & $\begin{array}{c}\text { 上記に下記の複数を } \\
\text { 併用 }\end{array}$ \\
\hline & & & LABA（配合剂使用可*5) & LABA（配合剂使用可*5) & LABA（配合剂使用可） \\
\hline & & LTRA & LTRA & LTRA & LTRA \\
\hline & & テオフィリン徐放製剂 & テオフィリン徐放製剤 & テオフィリン徐放製剤 & テオフィリン徐放製剤 \\
\hline & & ※症状が稀なら必要なし & & LAMA*6 & $\mathrm{LAMA}^{* 6}$ \\
\hline & & & & & 抗lgE抗体*2, 7 \\
\hline & & & & & 経ロステロイド薬*3, 7 \\
\hline & $\begin{array}{l}\text { 追加 } \\
\text { 治療 }\end{array}$ & $\begin{array}{c}\text { LTRA以外の } \\
\text { 抗アレルギ一薬*1 }\end{array}$ & $\begin{array}{l}\text { LTRA以外の } \\
\text { 抗アレルギ一薬*1 }\end{array}$ & $\begin{array}{l}\text { LTRA以外の } \\
\text { 抗アレルギ一薬*1 }\end{array}$ & $\begin{array}{c}\text { LTRA以外の } \\
\text { 抗アレルギ一薬*1 }\end{array}$ \\
\hline 発作流 & 台療*4 & 吸入SABA & 吸入 $S A B A * 5$ & 吸入 $S A B A * 5$ & 吸入SABA \\
\hline \multicolumn{6}{|c|}{ 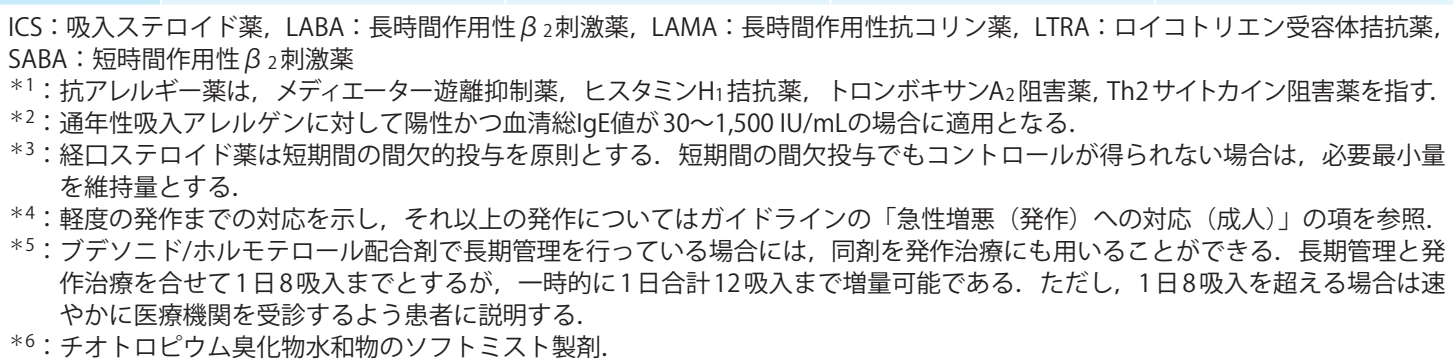 } \\
\hline
\end{tabular}

る.これで不十分であればLTRA, テオフィリン 徐放製凨, LAMAのいずれかを併用する.

\section{4）治療ステップ 4}

ICS（高用量）とLABAに加えて, LTRA, テオ フィリン徐放製剤, LAMAの複数を併用する. これらの投与でコントロールが困難な症例で, 通年性アレルゲンに感作されていて, かつ血清 総IgE值が治療標的範囲内（30 1,500 IU/ml) にある場合には, 抗IgE抗体の有用性が示されて いる. 経口ステロイド薬は短期間の間欠的な投 与を原則として, 可能な限り連用を回避する.
ロールに高用量ICSおよびLABA，加えてLTRA， テオフィリン徐放製剤，LAMA，経ロステロイ ド薬, 抗IgE抗体の投与を要する喘息, またはこ れらの治療でもコントロール不能な喘息」と定 義された。

難治性喘息/重症喘息の中には，ICSに対する 反応性が忘しく, 新規治療薬が必要な患者もい るが，多くは薬剤吸入手技や服用回数などの用 法に誤りがある場合や，喘息重症化に関与する 合併症の診断・治療の不適切さによることが報 告されている. JGL2015では難治性喘息/重症喘 息患者に対する対応手順と専門医への紹介の夕 イミングに関し，図2のように示している.

\section{6. 難治性喘息/重症喘息への対虑}

難治性喘息/重症喘息は, JGL2015で「コント 


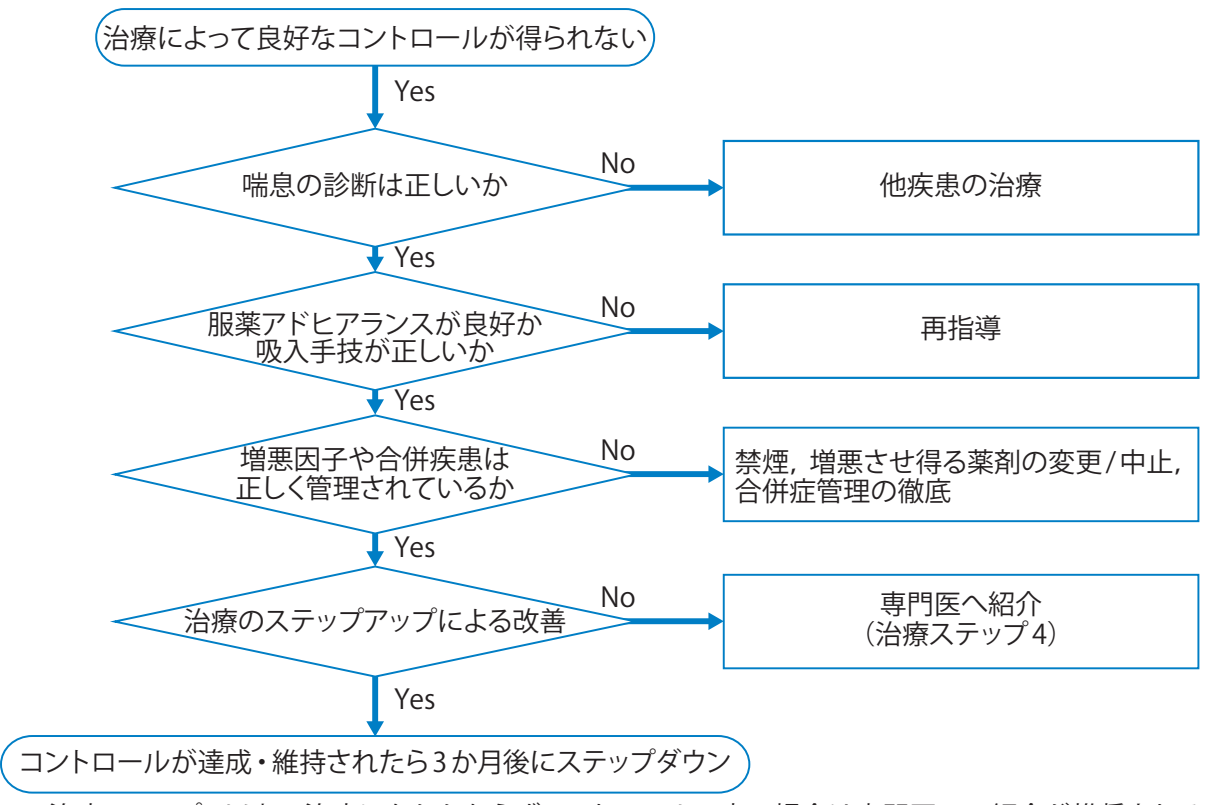

* : 治療ステップ3以上の治療にもかかわらずコントロール不良の場合は専門医への紹介が推奨される.

図 2 難治性喘息/重症喘息への対応（文献1より引用）

\section{おわりに}

以上，JGL2015に関して解説した．喘息の本 態は気道の炎症であり, 治療の要諦は気道炎症 の抑制と気道狭窄の解除にあり, ICSを中心と し，適宜気管支拡張薬を追加（add-on）する薬
物療法が中心をなす。もちろん, 抗原回避や禁 煙といった喘息悪化要因の回避が重要であるこ とはいうまでもない.

著者のCOI（conflicts of interest）開示：一ノ瀬正和；講 演料 (アステラス製薬，アストラゼネカ，日本ベーリン ガーインゲルハイム, ノバルティスファーマ)

1）「喘息予防・管理ガイドライン2015」作成委員会：喘息予防・管理ガイドライン2015. 共和企画, 東京，2015.

2）一八瀬正和：気管支喘息, 内科学. 門脇 孝, 永井良三編. 西村書店, 東京, 2012, 774-776.

3) Global strategy for asthma management and prevention. Updated 2015 http://www.ginasthma.org/ 